\title{
Economic Analysis of Smallholder Maize Producers: Empirical Evidence From Helmand, Afghanistan
}

\author{
Hamidullah Elham ${ }^{1}$, Jiajun Zhou ${ }^{1}$, Mouhamadou Foula Diallo ${ }^{1}$, Shakeel Ahmad ${ }^{1}$ \& De Zhou ${ }^{1,2}$ \\ ${ }^{1}$ College of Economics and Management, Nanjing Agricultural University, Nanjing, China \\ ${ }^{2}$ China Center for Food Security Studies, Nanjing Agricultural University, Nanjing, China \\ Correspondence: De Zhou, College of Economics and Management, Nanjing Agricultural University, No. 1, \\ Weigang, Xuanwu District, Nanjing 210095, China. Tel: 86-182-6007-5456. E-mail: zhoude@njau.edu.cn
}

Received: December 2, $2019 \quad$ Accepted: January 15, $2020 \quad$ Online Published: February 15, 2020

doi:10.5539/jas.v12n3p153 URL: https://doi.org/10.5539/jas.v12n3p153

\begin{abstract}
Since war started at the end of 2001, the economy was severely devasted in Afghanistan, especially for the agriculture sector. Maize is the third most important cereal crop in Afghanistan, but the productivity of maize has a declining trend which may be caused by low efficiency of maize farmers nowadays. This study examines the production efficiency of maize producers and its important factors with the cross-sectional data form a multi-stage sampling survey of 250 maize producers in Helmand province in 2019. With the adoption of stochastic production frontier (SPF) model and production cost function, the paper gets the estimations of the average technical efficiency (0.737), allocative efficiency (0.65) and economic efficiency (0.568). The inputs, including land, labor, seed, fertilizer and pesticide/weedicides, have significant impacts on maize production and most of the farms exhibit an increasing return to scales. In addition, Tobit regression was applied to identify the influential factors of the production efficiencies for maize producers and the results indicate that education, family size, farm size, farming experience, contact to extension services and access to credit have significantly influence on the efficiency level. Finally, the study suggests that government should take some initiatives, such as extending the agricultural extension service, ensuring supply of high quality seeds and sufficient fertilizer with affordable prices and economical provision of mobile internet facility in remote areas, which will enhance the productivity and efficiency of the farmers and ultimately boost up their economic welfare and livelihood.
\end{abstract}

Keywords: maize production, technical efficiency, stochastic frontier analysis, Tobit model, Afghanistan

\section{Introduction}

Agriculture is the main contributor to the economy of Afghanistan as it accounted for 23\% of the national GDP and employed 44\% of labor force in 2017 (CIA, 2019). It also provides household income, food security and employment for more than $80 \%$ of the population in rural areas. However, agriculture sector is still associated with poor performance and not enough to feed the population. Since 2001, conflict with USA was emerged and political forces tried to establish a modernized economy. And there were drastic policy changes which would affect the agriculture sector tremendously, especially for the grain crops (Ahmadzai, 2017). But the value-added agriculture still declines since 2002 .

In Afghanistan, maize is the third largest cereal crop and has a vital role in the developing economy of Afghanistan where the expanding population is still partially undernourished. When traditional wheat and rice become scarce, most of the people use maize as an alternative source of food. Therefore, maize is also important for the food security in Afghanistan as more than 54\% population are living below the poverty line (CIA, 2019).

Maize productivity fluctuated and is decreasing in past years. In 2017, Afghan maize production was 0.174 million tons, 44\% decrease of 0.312 million tons production in 2016 (FAOSTAT, 2017). The productivity of maize in Afghanistan is substantially lower than that in its neighboring countries (Table 1). The low productivity of maize is mainly caused by the lack of knowledge for efficient use of inputs and poor management skills. Given the importance of maize, the increase of maize productivity is very helpful for improving the food security in rural areas of Afghanistan. Thus, it is necessary for farmers to use the available resources in most efficient ways and to achieve a higher productivity in maize production and a better food security (Obaidi et al., 2012; Ngabitsinze, 2014). 
Table 1. Production and productivity of maize in Afghanistan and its neighboring countries in 2017

\begin{tabular}{llll}
\hline Country/Region & Area harvested (million ha) & Yield (t/ha) & Production (million tons) \\
\hline World + (Total) & 197 & 5.75 & 1134 \\
Asia + (Total) & 67 & 5.37 & 361 \\
Afghanistan & 0.13 & 1.29 & 0.17 \\
India & 9.2 & 3.11 & 28.7 \\
Iran & 0.17 & 7.02 & 1.2 \\
Pakistan & 1.2 & 4.63 & 5.7 \\
\hline
\end{tabular}

Source: FAOSTAT, 2017.

Agriculture sector is dominated by the small farmers in Afghanistan (Ngabitsinze, 2014). Most of the small framers hold very low productivity due to high inefficiencies (technical, allocative and economic). Some studies have identified the problems, such as lack of capital, fluctuated prices, shortage of crop storage facility, ineffective agronomic methods, poor management practices, low quality seeds, high cost of inputs and sudden changes in temperature, that affect the efficiency and result in low productivity of farming (Ahmadzai, 2017; Mangal et al., 2017; Rajiv Sharma, 2018). Several studies also highlighted many issues, like mismanagement practices at farm, high fragmentation of land, poor availability of credit, high costs of inputs, low adoption of advanced agricultural technology, low education level for farmers, lack of extension services, poor roads and infrastructure, are main impediments for the improvement of agricultural production in Afghanistan (Bell, 2012; Jilani et al., 2013; Maletta \& Favre, 2003; Tavva et al., 2017; Thomas \& Ramzi, 2011).

Increasing agricultural production and improving self-sufficiency of staple food have profound significance for the poverty elimination in Afghanistan and analyzing the efficiency of agricultural production, especially maize production is very important to reveal the approaches to improve the performance of the maize farmer. As one major maize production region, Helmand province encounters many restrictions including limited inputs and poor financial resources etc. (Saleem \& Raouf, 2011; Sarhadi et al., 2014). The major objective of the present study is to evaluate the economic, allocative and technical efficiencies of maize producers in Helmand province in Afghanistan and explore the determinants of maize producers' inefficiency. In addition, this knowledge can help policymakers to reshape the policies and strategies to enhance the efficiency of maize production and improve the food security in Afghanistan.

The remaining parts of this paper are organized as follows: section 2 describes material and methods, while section 3 presents the empirical results and finally section 4 introduces the discussions. In the end, policy implications are concluded.

\section{Materials and Methods}

\subsection{Study Area}

The major maize cultivation region is the south-west region with $42 \%$ of total national maize production. Within this region, Helmand province was the second largest maize producer (Ministry of Agriculture, 2012) and maize is the largest crop produced in summer season with 60200 hectares in this province (DIAL, 2016). This research was conducted in Helmand province where maize was produced for both domestic consumption and export. Helmand Province is one of the largest provinces in Afghanistan, covering 58584 square kilometers. About 0.85 million population settle in this province and $94 \%$ of which are living in rural areas with poor literacy rate of only $5 \%$ and agriculture provides the main means of livelihood. In the past years, Helmand made a great contribution in agricultural production because of its organized irrigation canal system which was developed under the "Helmand River Valley Project". According to Ali Ahmad and George (2016), about 0.15 million hectares $(70 \%$ of land) irrigated by the canal system. 


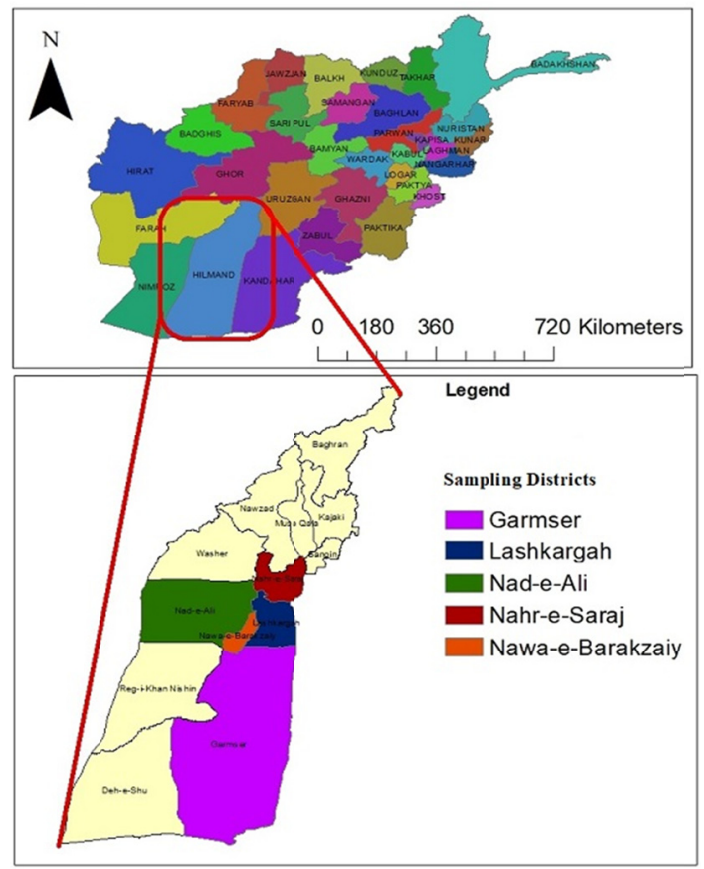

Figure 1. Map of study area

\subsection{Sampling and Data Collection}

The farm household survey was conducted in 2019 summer production season. 250 farmers were interviewed with multi-stage sampling technique. Four-stages were involved to select farmers in the study area: (1) 5 of 14 districts were selected in the southern part of the Helmand province as these (Nawa, Garamsir, NahreSarraj, Lashkar Gah, Nad Ali) districts are the main maize production areas (Table 2), (2) two units (towns) in each district were selected, (3) three villages were chosen from each unit, (4) 8-9 farmers who were producing maize were randomly selected in each village. The detailed information on socioeconomics and demographics of households, farm characteristics, inputs usage and outputs, institutional linkages and marketing were also collected.

Table 2. Maize production in Helmand Province in 2016

\begin{tabular}{lll}
\hline District & Maize Crop Area (ha) & Maize production (tons) \\
\hline Nawa & 7000 & 34300 \\
Garamsir & 7500 & 36750 \\
Khanishin & 2200 & 10780 \\
Dishu & - & - \\
Lashkargah & 4500 & 22050 \\
Nad Ali & 5000 & 24500 \\
Marja & 800 & 3920 \\
Nahresiraj & 13000 & 63700 \\
Sangain & 5000 & 24500 \\
Musa Qala & 1200 & 5880 \\
Kajaki & 2500 & 12250 \\
Nowzad & 6000 & 29400 \\
Baghran & - & - \\
Washir & 5500 & 26950 \\
Total & 60200 & 294980 \\
Average yield per ha (tons) & & 4.9 \\
\hline Source: DAIL(Depart
\end{tabular}

Source: DAIL (Department of Agriculture, Irrigation and Livestock), 2016. 


\subsection{Empirical Model}

Agricultural productivity can be measured as total output/input ratio. Productivity of maize crop can be improved with different means. For example, it can be enhanced by proper utilization of resources and improving the efficiency of maize producers. When it comes to the production efficiency, we followed the methodology of Stochastic Frontier Production function (SFP) to estimate maize production efficiency (Aigner et al., 1977). Cobb-Douglas Production Function for maize farmers was employed in this study.

$$
\ln \mathrm{Y}_{\mathrm{i}}=\beta_{0}+\sum_{\mathrm{n}=1}^{5} \beta \cdot \ln \mathrm{X}_{\mathrm{i}}+\left(\mathrm{V}_{\mathrm{i}}-\mathrm{u}_{\mathrm{i}}\right)
$$

where, $Y_{\mathrm{i}}$ represents the total output of $i^{\text {th }}$ farmer; $\beta$ is the vector of parameters to be estimated and $X_{\mathrm{i}}$ is the vector of inputs used for maize production, while $\mathrm{V}_{\mathrm{i}}$ measure the random variation assumed to be an iid $N\left(0, \sigma_{v}^{2}\right)$ in $\mathrm{Y}_{\mathrm{i}}$ due to the factors beyond the control of the farmer, and $\mathrm{u}_{\mathrm{i}}$ is inefficiency error term which is a non-negative random variable associated with technical inefficiency of production and assumed to be an independent distribution of $N\left(u, \delta_{u}^{2}\right)$. Technical Efficiency (TE) of any farm could be defined as the ratio of observed output to the potential output defined by the frontier function. Following the Cobb-Douglas production function, TE can be measured with ratio of output values and estimated frontier values as follows.

$$
\mathrm{TE}_{\mathrm{i}}=\frac{\exp \left(\mathrm{Y}_{\mathrm{i}}\right)}{\exp \left(\beta_{0}+\sum_{\mathrm{n}=1}^{5} \beta \cdot \ln \mathrm{X}_{\mathrm{i}}+\mathrm{V}_{\mathrm{i}}\right)}=\exp \left(-\mathrm{u}_{\mathrm{i}}\right)
$$

By following the method of Efficiency Decomposition Technique (EDT) from Bravo-Ureta and Rieger (1991), on the basis of Equation 2 we can estimate the dual cost function and it will provide the basis to measure the economic efficiency (EE) and allocative efficiency (AE) of individual farm.

$$
\ln C=\alpha_{0}+\alpha_{1} \ln C_{1}+\alpha_{2} \ln C_{2}+\alpha_{3} \ln C_{3}+\alpha_{4} \ln C_{4}+\alpha_{5} \ln C_{5}+\varphi \ln Y_{i}+\mu_{i}
$$

Where, $\mathrm{C}$ is the total cost of production for maize of farm $i, C_{1}$ is cost of land which is taken as the market price of rented land per hectare. $C_{2}$ is market price of labor per day, $C_{3}$ is the cost of fertilizer per $\mathrm{kg}, C_{4}$ is the cost of seed per $\mathrm{kg}$ and $C_{5}$ is the total cost of other inputs such as pesticide, weedicides/herbicides per liter of market price. Whereas, the $Y_{i}$ represents the output of maize in $\mathrm{kg}$. We estimated the maximum likelihood parameters in stochastic frontier production function (SFP) and efficiency decomposition technique (EDT) with STATA 13.

Economic efficiency is the ability of farmers to use a minimum production cost of inputs while producing the maximum possible output, given the available technology. Bear in mind that economic efficiency is a product of technical efficiency and allocative efficiency (Abdulai , Nkegbe, \& Donkor, 2017). Thus, the relationship is denoted as follows:

$$
\mathrm{EE}_{\mathrm{i}}=\mathrm{TE}_{\mathrm{i}} \times \mathrm{AE}_{\mathrm{i}}
$$

Where, $\mathrm{EE}_{\mathrm{i}}$ is the economic efficiency of the ith farmer, $\mathrm{TE}_{\mathrm{i}}$ is the technical efficiency of the ith farmer and $\mathrm{AE}_{\mathrm{i}}$ is the allocative efficiency of the $\mathrm{i}^{\text {th }}$ farmer.

To estimate the impacts of demographic, socioeconomic, institutional linkages, farm characteristics and marketing variables on efficiencies, we regressed the efficiencies scores which are valued between zero and one on independent variables with Tobit model (Maddala, 1986; Dhungana et al., 2004; Ibrahim \& Omotesho, 2013; Javed et al., 2008; Krasachat, 2004; Tobin, 1958).

$$
\mathrm{E}_{\mathrm{i}}=\mathrm{E}_{\mathrm{i}}^{*}=\mathrm{Y}^{0}+\sum_{\mathrm{j}=1}^{\mathrm{k}} \mathrm{YZ}_{\mathrm{i}}+\varepsilon_{\mathrm{i}}
$$

Where, $E_{i}$ represents the technical, allocative and economic efficiency respectively, $E_{i}^{*}$ is the latent variable, $\gamma$ is the vector of unknown parameters, $Z_{\mathrm{i}}=$ is vector of selected explanatory variables of $i^{\text {th }}$ farmer and $\varepsilon_{\mathrm{i}}$ is the error term. The summary of all variables used in Tobit model is presented in Table 3. 
Table 3. Descriptive summary of surveyed maize producers $(n=250)$

\begin{tabular}{llll}
\hline Variables & Unit & Description of Variables & Mean (S.D.) \\
\hline Age & Years & Age of the farmer & $43.92(14.74)$ \\
Family Size & Numbers & number of persons in family & $12.92(4.12)$ \\
Education & Years & Formal Education in years & $5.16(4.72)$ \\
Farming Exp & Years & Farmer's Experience in maize production & $19.69(11.21)$ \\
Farm Size & Hectare & Total cultivation land & $2.94(1.42)$ \\
Liv Assets & Number of Heads & Total number of Animals on farm & $4.48(2.56)$ \\
CES & Number of times & Frequency of contact with extension officers & $2.06(0.07)$ \\
Access to Credit & Dummy & Access to get credit from banks or other sources & $0.54(0.03)$ \\
MFG & Dummy & Membership of Farmer Group & $0.71(0.03)$ \\
DtR & KM & Distance between farm and main road & $1.45(0.78)$ \\
DNM & KM & Distance from farm to the nearest market & $4.33(3.68)$ \\
Mobile/Internet & Dummy & Usage of Mobile or internet for information about production & $0.64(0.03)$ \\
\hline
\end{tabular}

\section{Empirical Results}

Estimations of SFP model and cost function are presented in Table 4. Results show that Land, seed, fertilizer, weedicides/pesticides and labor significantly affect the maize production. It also indicates that if labor increases just $1 \%$ maize output would increase $0.24 \%$. The coefficients of remaining variables such as land, seed, fertilizer and weedicides are all positive which means more those inputs will lead the growth of maize production. The estimations of Likelihood ratio test, $\delta^{2}$ and $\gamma$ indicating that model was significant and the existence of inefficiency component. Returns to scale was 1.021 showing the increasing returns on the scale of maize production function.

Table 4. Maximum likelihood estimations of parametric SFP and cost function of maize production

\begin{tabular}{|c|c|c|c|}
\hline Variables & $\begin{array}{l}\text { ML Estimation of SPF } \\
\text { Coef. (Std. Err.) }\end{array}$ & Variables & $\begin{array}{l}\text { Estimation of Cost Function } \\
\text { Coef. (Std. Err.) }\end{array}$ \\
\hline Constant & $2.98^{* * *}(0.291)$ & Constant & $1.54^{* *}$ \\
\hline $\ln$ land & $0.46^{* * *}(0.034)$ & $\ln C_{\text {land }}$ & $0.18^{* * *}$ \\
\hline $\ln$ labor & $0.24^{* *}(0.028)$ & $\ln C_{\text {labor }}$ & $0.12^{* *}$ \\
\hline $\ln$ Seed & $0.08^{* * *}(0.014)$ & $\ln \mathrm{C}_{\text {seed }}$ & $0.19^{* * *}$ \\
\hline In Fertilizer & $0.10^{* * *}(0.025)$ & $\ln C_{\text {fertilizer }}$ & $0.21^{* * *}$ \\
\hline ln Weedicides & $0.13^{* * *}(0.011)$ & $\operatorname{lnC} C_{\text {weedicides }}$ & $0.10^{* * *}$ \\
\hline Log-Likelihood & -238.14 & $\ln C_{\text {output }}$ & $0.13^{* * *}$ \\
\hline Returns on scale & 1.021 & & \\
\hline Sigma square $\delta^{2}=\delta_{{ }_{u}}^{2}+\delta_{v}^{2}$ & $3.54^{* * *}(0.31)$ & & \\
\hline$\gamma=\delta^{2}{ }_{\mathrm{u}} / \delta^{2}$ & $0.64^{* * *}(0.05)$ & & \\
\hline
\end{tabular}

We also estimated the dual cost frontier function with which to measure the allocative (AE) and finally derived the economic efficiency (EE). All the variables in cost function include land, labor, seed, fertilizer and weedicides have positive and significant impacts on total cost of maize production. Particularly, $1 \%$ increase of cost of seed, fertilizer, land, output, labor and weedicides would increase the total production cost by $0.19 \%$, $0.21 \%, 0.18 \%, 0.13 \%, 0.12 \%$ and $0.10 \%$ respectively. 
Table 5. Summary statistics of estimated efficiencies

\begin{tabular}{lllll}
\hline Type of Efficiency & Average & Maximum & Minimum & Std. Dev. \\
\hline Technical Efficiency (TE) & 0.737 & 0.971 & 0.216 & 0.163 \\
Allocative Efficiency (AE) & 0.652 & 0.932 & 0.392 & 0.964 \\
Economic Efficiency (EE) & 0.568 & 0.906 & 0.087 & 0.231 \\
\hline
\end{tabular}

Table 5 presents the summary of all estimated efficiency-TE, AE and EE. The mean of TE for sampled farms is 0.737 with the range of $[0.216,0.971]$. This implies that the average maize producer only attains $74 \%$ of potential output under the prevailing technology. Allocative efficiency is at an output level where the price equals the marginal cost $(\mathrm{MC})$ of production. The average $\mathrm{AE}$ is 0.652 with a range of $[0.392,0.932]$. It suggests that the maize farmers produced up to the average of $65 \%$ allocative efficiency point, and there is some space to optimize the inputs structure of maize production. Finally, with mean of 0.568 , economic efficiency holds the interval of $[0.087,0.906]$, it is evident that there is a need to improve both technical and allocative efficiency in maize production in Helmand province. Particularly, the result suggests that a potential of $44 \%$ improvement of economic efficiency would be achieved by optimizing the inputs structure and improving production technical efficiency.

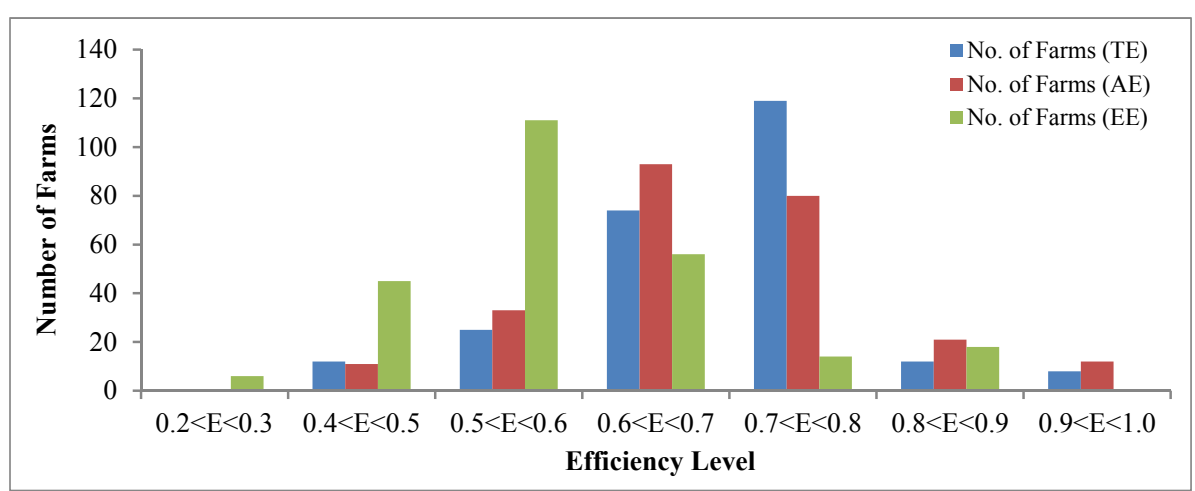

Figure 2. Distribution of technical, allocative and economic efficiency for farms in Helmand

The distribution of economic, allocative and technical efficiencies is presented in Figure 2. The technical efficiency of majority of farms (about $48 \%$ ) locate to the category of $0.7<\mathrm{E}<0.8$, while for more than 90 farmers, the allocative efficiencies are in the range of $0.6<\mathrm{E}<0.7$. And $44 \%$ of the farms get economic efficiency of $0.5<\mathrm{E}<0.6$. Moreover, less than 20 farmers achieve the higher level of AE, TE and EE. Thus, farmers have the potential to achieve the maximum yield of maize by improving their efficiencies.

The evaluations of the determinants of TE, AE and EE were also performed with the use of Tobit model. To achieve robust estimates, some verification tests were also conducted including multicollinearity and heteroscedasticity check with Variance Influence Factor (VIF) and Breusch-Pagan test respectively. The results indicate that VIF is of 2.85 which indicates there is non-existence of multicollinearity, while Breusch-Pagan chi-square values for $\mathrm{EE}, \mathrm{AE}$ and $\mathrm{TE}$ are 1.84, 0.98 and 0.87 respectively, indicating that heteroscedasticity is not a problem in our models. Furthermore, Jargue-Bera test was applied to check for normality and the results (TE = $27.20, \mathrm{AE}=23.03$ and $\mathrm{EE}=20.83$ ) verified that values of the efficiencies were normally distributed. The results of the Tobit models are presented in Table 6. 
Table 6. Estimates of Tobit Regression Models

\begin{tabular}{|c|c|c|c|c|c|c|}
\hline \multirow{2}{*}{ Variables } & \multicolumn{2}{|c|}{ Technical Efficiency } & \multicolumn{2}{|c|}{ Allocative Efficiency } & \multicolumn{2}{|c|}{ Economic Efficiency } \\
\hline & Coefficient & Std. Err. & Coefficient & Std. Err. & Coefficient & Std. Err. \\
\hline Age & -0.003 & 0.002 & $-0.002^{* *}$ & 0.001 & -0.002 & 0.003 \\
\hline Family Size & 0.002 & 0.004 & $-0.006^{* *}$ & 0.003 & -0.001 & 0.004 \\
\hline Education & $0.004^{* *}$ & 0.002 & $0.003^{* * *}$ & 0.001 & $0.002^{* *}$ & 0.001 \\
\hline Farming Exp. & $0.009^{* * *}$ & 0.003 & 0.004 & 0.003 & $0.005^{* *}$ & 0.002 \\
\hline Farm Size & $0.006^{* * *}$ & 0.002 & -0.001 & 0.002 & $0.004^{* * *}$ & 0.001 \\
\hline Liv. Assets & 0.002 & 0.004 & 0.002 & 0.004 & 0.001 & 0.002 \\
\hline CES & 0.006 & 0.020 & $0.042^{* *}$ & 0.018 & 0.024 & 0.017 \\
\hline Access to Credit & $0.021^{* * *}$ & 0.002 & -0.002 & 0.012 & 0.004 & 0.010 \\
\hline MFG & $0.041^{* * *}$ & 0.015 & 0.029 & 0.019 & 0.037 & 0.024 \\
\hline DtR & -0.001 & 0.018 & $0.009^{* * *}$ & 0.003 & -0.002 & 0.010 \\
\hline DNM & -0.002 & 0.010 & 0.004 & 0.022 & $-0.002^{*}$ & 0.001 \\
\hline Mobile/Internet & $0.061^{* * *}$ & 0.019 & $0.047^{*}$ & 0.026 & $0.056^{*}$ & 0.030 \\
\hline Constant/intercept & 0.032 & 0.021 & 0.030 & 0.051 & $0.067^{* *}$ & 0.028 \\
\hline
\end{tabular}

Note. $* * *, * *$, and $*$ denotes significance level at $1 \%, 5 \%$ and $10 \%$ respectively.

According to the results, Age and household size negatively influence AE but are insignificant for TE and EE. This implies that older farmers and larger farmers were less efficient than their counterparts. The results also indicate that educated farmers hold higher technical, allocative and economic efficiencies and farming experience and farm size have positive and significant influences on TE and EE. This implies that farmers with a large land holding achieved higher levels of technical and economic efficiencies. Even though owning a large number of animals could provide manure, working power like oxen and household income, livestock asset (proxy of wealth status) is insignificant in the models. We also find that the frequency of contact with extension service agencies and distance between farm and main road increased farmers' allocative efficiency. The credit access and membership of farmer groups could improve technical efficiency. When it comes to the impacts of market, we find that those who are near the market get higher economic efficiency than the households that are far away from the market. Finally, mobile phone/internet usage empowers maize farmers to be more technically, allocatively and economically efficient.

\section{Discussion}

\subsection{Stochastic Frontier Production Function, Cost Function and Efficiencies}

The results indicate that land has positive relationships with maize production and cost which is consistent with the results from Ahmadzai (2017), and Debebe et al. (2015) who found that land had the largest effect on maize production in Ethiopia. We found that the most essential factor in maize production function is labor that is similar with the results from Sapkota et al. (2017), because most maize farmers in Afghanistan use labor-intensive methods in production. Regarding other inputs, several studies found that seed (Ng'ombe \& Kalinda, 2015), fertilizer (Chirwa, 2007) and pesticides/weedicides (Debebe et al., 2015) also had significant and positive effects on maize output. It also performs the same way in the cost function (Abdulai et al., 2017; Debebe et al., 2015). Thus, taking the existing literature into consideration, the estimations in the present study are reasonable.

On average, the economic efficiency, allocative efficiency and technical efficiency for maize farmers are $57 \%$, $65 \%$ and $73 \%$ respectively. As we mentioned before that Allocative efficiency (AE) is one indicator that the farmer could make a choice and utilize the inputs in maize production to reach a level where their factor prices equal marginal returns (Tijani, 2006). The results of the allocative efficiency indicate the inputs are either over-used or under-used in maize production in Helmand province. On the other hand, technical efficiency is the ability of a farmer to produce potential maximum output given a set of inputs and available production technology (Koopmans, 1951). The results reveal many maize farmers could produce at the level close to the potential production. Furthermore, improvement of $\mathrm{AE}$ and TE would greatly contribute the growth of EE. Thus, our results suggest that maize farmers in Afghanistan did not master the cost minimization in production which would lead the poor performance of maize production. 


\subsection{Determinants of Efficiencies}

The results show that production efficiency tends to decrease as the age of farmers grows. Even though farmers acquire more experience in farming practice as time goes by and could efficiently utilize the resources for maize production (Amos, 2007; Chaovanapoonphol \& Somyana, 2018; Msuya et al., 2008; Sibiko, 2012), farmers become less energetic as them get older and this affects their productivity which could be the reasonable case in our study. This result is in line with the finding from Taiwo et al. (2014) and Tavva et al. (2017) who found that efficiency in cassava and wheat production declined as the farmers got older. Amaza et al. (2006) and Chepng'etich et al. (2014) also reported that younger farmers are more energetic and keener to adopt advanced production technologies, thereby making them to achieve higher efficiency.

The household size is another important influential factor of the efficiency of maize production in Helmand province in Afghanistan. Particularly, larger families have enough labor forces to perform farming activities, especially for the labor-intensive maize production. This is consistent with the discourse that larger households have more domestic labor to deploy at the farm, especially in the time of labor shortage (Asefa, 2011; Aye \& Mungatana, 2011; Debebe et al., 2015; Elibariki et al., 2008). However, we found that it negatively affects allocative efficiency, and this could be caused by the resource misallocation in productions such as overutilization of labor (Abdulai \& Eberlin, 2001; Donkoh et al., 2013; Mwalupaso et al., 2019; Tavva et al., 2017).

Regarding education, most of the studies concluded that educated farmers are more efficient than their counterparts (Abdulai et al., 2017; Chaovanapoonphol \& Somyana, 2018; Debebe et al., 2015; Mussaa et al., 2011; Nyagaka et al., 2010; Shehu et al., 2010; Tavva et al., 2017). Also, some researchers (Anang et al., 2016; Asante et al., 2014; Donkoh et al., 2013) reported contrary findings as they are more engaged in off-farm employments which may deter their farming activities. Our finding indicates that highly educated farmers could easily perceive instructions of maize production and are more apt to learn and adopt new skills and technologies in maize production and then get higher efficiencies.

Farming experience could increase the capacity of farmers in maize production. Hence, efficiency is positively influenced by the farming experience in present study. This is in line with the result of Abdulai et al. (2017), Gul et al. (2009), Mwalupaso et al. (2019), Okike et al. (2004), Olarinde (2011), and Sapkota et al. (2017) who found that experienced farmer can acquire better knowledge and skills to select the suitable farm equipment. When it comes to farm size, there are some studies identified that small farms hold higher production efficiency because of easy management and lower transaction cost (Adebanjo Otitoju \& Arene, 2010; Amos, 2007; Elibariki et al., 2008; Idiong et al., 2009; Mwalupaso et al., 2019). Many other researchers found a positive relationship between efficiency and farm size as large farms are more efficient because modern agricultural techniques can easily be adopted and scale economies make them more productive (Chaovanapoonphol \& Somyana, 2018; Chirwa, 2007; Endrias et al., 2010; Gul et al., 2009; Msuya et al., 2008). Our results also present positive impacts of farm size on efficiency.

Strikingly, institutional linkages like contact with extension service agencies perform a crucial role in the agricultural production and efficiency improvement for maize farmers in Afghanistan. More frequent contact with extensions services high likely provide farmers useful instructions and improve inputs allocation, cost reduction and augmented production (Abdulai et al., 2017; Aboki et al., 2013; Debebe et al., 2015; Peprah, 2010; Sapkota et al., 2017; Sibiko, 2012). However, the distance from the markets is one barrier for obtaining inputs and extension services which ultimately affects farmers' technical efficiency (Anang et al., 2016; Martey, 2019; Ng'ombe \& Kalinda, 2015).

Credit access is pivotal for enhancing production efficiency and its impacts on TE are positive and significant, because financial credit enables farmers to extend and manage their farms and improves the agricultural production system (Chepng'etich et al., 2014; Nchare, 2007; Ng'ombe \& Kalinda, 2015; Olarinde, 2011). Participation in farmers' organization/association/groups is another cardinal factor because farmers can enjoy the group benefits of scale economy, better extension services and access to inputs. The positive effect of membership of farmers group on efficiency level has also been reported in many studies that group membership reduced the cost of production and enhanced the productivity, profitability and production efficiencies (Aboki et al., 2013; Anang et al., 2016; Sudrajat et al., 2018). Finally, information technique adoption increases the potential production for adopting better practices and prevent farmers from making blind decisions which leads to the improvement in efficiency (Debebe et al., 2015; Sekabira \& Qaim, 2017). 


\section{Conclusion and Policy Recommendations}

Maize is the strategic crop and staple food in Afghanistan. However, its declining productivity in recent years poses a great threat to the poverty reduction and hunger eradication in the country. Therefore, this paper empirically examines the technical, allocative and economic efficiency of maize production with stochastic frontier analysis and cost function regression based on the data collected from Helmand province in Afghanistan. The results indicate that all the classical inputs significantly contribute to maize productivity, and fertilizer and seed have larger shares in the total cost of maize production. The average efficiency levels $(\mathrm{EE}=0.56, \mathrm{AE}=0.65$ and $\mathrm{TE}=0.737$ ) reveal that there is potential space to increase maize output with optimizing inputs structure and production technology adoption to improve the technical efficiency and allocative efficiency.

Furthermore, to scale up the efficiency levels, policies must be directed towards the positive determinants, such as education, farming experience, contact with extension services, farm size, membership of farmer group, access to credit and mobile phone/internet usage, as well as the those with negative influences, such as age and distance between local input/output market. Overall, the proper allocation and utilization of available resources (inputs) and advanced production technology should be prioritized to leverage the benefits maximization in maize production.

Specific measures for maize productivity improvement in developing country like Afghanistan should take the training and information for maize producers into consideration. Policymakers should also promote initiatives to make extension services for small farmers more effective. Furthermore, provincial administration should ensure the supply of quality seeds, and high prices of fertilizers must also be addressed through farmer inputs support program (FISP). Lastly, better internet and mobile networks are necessary for the availability of information on technologies and markets in rural areas which eventually could improve the productivity.

\section{Acknowledgements}

We thank the funding from Chinese Scholarship Council (CSC). The supports from the Chinese Pear Industry Technology System: Industrial Economy Research (NYCYTX-29-17), Chinese Academy of Engineering Consultative Project (2020-XZ-20), National natural Science Foundation of China (NSFC: 71703071), “A Project Funded by the Priority Academic Program Development of Jiangsu Higher Education Institutions (PAPD)" and "China Center for Food Security Studies, Nanjing Agricultural University" are acknowledged. The comments and suggestions from editor and reviewers are appreciated.

\section{References}

Abdulai, A., \& Eberlin, R. (2001). Technical efficiency during economic reform in Nicaragua: evidence from farm household survey data. Economic Systems, 25, 113-125. https://doi.org/10.1016/S0939-3625 (01)00010-3

Abdulai, S., Nkegbe, P. K., \& Donkor, S. A. (2017). Assessing the Economic Efficiency of Maize Production in Northern Ghana. Ghana Journal of Development Studies, 14, 123-145. https://doi.org/10.4314/gjds.v14i1.7

Aboki, E., Jongur, A., Onu, J., \& Umaru, I. (2013). Analysis of technical, economic and allocative efficiencies of cassava production in Taraba State, Nigeria. IOSR Journal of Agriculture and Veterinary Science, 5, 19-26. https://doi.org/10.9790/2380-0531926

Adebanjo Otitoju, M., \& Arene, C. (2010). Constraints and determinants of technical efficiency in medium-scale soybean production in Benue State, Nigeria. African Journal of Agricultural Research, 5, 2276-2280.

Ahmadzai, H. (2017). Crop diversification and technical efficiency in Afghanistan: Stochastic frontier analysis. CREDIT Research Paper.

Aigner, D., Lovell, C. K., \& Schmidt, P. (1977). Formulation and estimation of stochastic frontier production function models. Journal of Econometrics, 6, 21-37. https://doi.org/10.1016/0304-4076(77)90052-5

Ajewole, O., \& Folayan, J. (2008). Stochastic frontier analysis of technical efficiency in dry season leaf vegetable production among smallholders in Ekiti State, Nigeria. Agricultural Journal, 3, 252-257.

Ali Ahmad, \& George, D. P. (2016). Farming system of Helmand province, Afghanistan. International Journal of Multidisciplinary Research and Development, 3, 197-201.

Amaza, P., Bila, Y., \& Iheanacho, A. (2006). Identification of factors that influence technical efficiency of food crop production in West Africa: Empirical evidence from Borno State, Nigeria. Journal of Agriculture and Rural Development in the Tropics and Subtropics, 107, 139-147. 
Amos, T. T. (2007). An analysis of productivity and technical efficiency of smallholder cocoa farmers in Nigeria. Journal of Social Sciences, 15, 127-133. https://doi.org/10.1080/09718923.2007.11892573

Anang, B. T., Bäckman, S., \& Sipiläinen, T. (2016). Agricultural microcredit and technical efficiency. Journal of Agriculture and Rural Development in the Tropics and Subtropics.

Asante, B., Wiredu, A., Martey, E., Sarpong, D., \& Mensah-Bonsu, A. (2014). NERICA adoption and impacts on technical efficiency of rice producing households in Ghana: implications for research and development. American Journal of Experimental Agriculture, 4, 244. https://doi.org/10.9734/AJEA/2014/7250

Asefa, S. (2011). Analysis of technical efficiency of crop producing smallholder farmers in Tigray, Ethiopia.

Aye, G. C., \& Mungatana, E. D. (2011). Technological innovation and efficiency in the Nigerian maize sector: Parametric stochastic and non-parametric distance function approaches. Agrekon, 50, 1-24. https://doi.org/ 10.1080/03031853.2011.617870

Bell, S. H. A. M. (2012). Maize overview. Information sheet.

Bravo-Ureta, B. E., \& Rieger, L. (1991). Dairy farm efficiency measurement using stochastic frontiers and neoclassical duality. American Journal of Agricultural Economics, 73, 421-428. https://doi.org/10.2307/ 1242726

Chaovanapoonphol, Y., \& Somyana, W. (2018). Production efficiency of maize farmers under contract farming in Laos PDR. Kasetsart Journal of Social Sciences. https://doi.org/10.1016/j.kjss.2018.06.006

Chepng'etich, E., Bett, E. K., Nyamwaro, S. O., \& Kizito, K. (2014). Analysis of technical efficiency of sorghum production in lower eastern Kenya: A data envelopment analysis (DEA) approach.

Chirwa, E. W. (2007). Sources of technical efficiency among smallholder maize farmers in Southern Malawi. AERC.

CIA (Central Intelligence Agenc). (2019). World Factbook, Afghanistan Economy 2017.

CSO (Central Statistic Organization of The Islamic Republic of Afghanistan). (2009, 2010). The Central Statistics Office, $1388-1389$ (p. 14).

Debebe, S., Haji, J., Goshu, D., \& Edriss, A.-K. (2015). Technical, allocative, and economic efficiency among smallholder maize farmers in Southwestern Ethiopia: Parametric approach. Journal of Development and Agricultural Economics, 7, 282-291. https://doi.org/10.5897/JDAE2015.0652

Dhungana, B. R., Nuthall, P. L., \& Nartea, G. V. (2004). Measuring the economic inefficiency of Nepalese rice farms using data envelopment analysis. Australian Journal of Agricultural and Resource Economics, 48, 347-369. https://doi.org/10.1111/j.1467-8489.2004.00243.x

Donkoh, S. A., Ayambila, S., \& Abdulai, S. (2013). Technical efficiency of rice production at the Tono irrigation scheme in northern Ghana. American Journal of Experimental Agriculture, 3(1), 25-42. https://doi.org/ 10.9734/AJEA/2013/1448

Elibariki, E., Shuji, H., \& Tatsuhiko, N. (2008). An analysis of technical efficiency of smallholder maize farmers in Tanzania in the globalization era. Contributed paper and presented in the XII World Congress of Rural Sociology of the International Rural Sociology Association, Goyang, Korea.

Endrias, Z., Yechale, T., \& Assefa, M. (2010). Bovine hydatidosis in Ambo municipality abattoir, West Shoa, Ethiopia. Ethiopian Veterinary Journal, 14, 1-14.

FAOSTAT. (2017). FAOSTAT statistical database. FAO (Food and Agriculture Organization of the United Nations), Rome, Italy.

Forero, M. D. P. B. (2013). Mobile communication networks and Internet technologies as drivers of technical efficiency improvement. Information Economics and Policy, 25, 126-141. https://doi.org/10.1016/ j.infoecopol.2012.11.004

Gul, M., Koc, B., Dagistan, E., Akpinar, M. G., \& Parlakay, O. (2009). Determination of technical efficiency in cotton growing farms in Turkey: A case study of Cukurova region. African Journal of Agricultural Research, 4, 944-949.

Ibrahim, H., \& Omotesho, O. (2013). Determinant of technical efficiency in vegetable production under Fadama in northern guinea savannah, Nigeria. Journal of Agricultural Technology, 9, 1367. 
Idiong, I., Agom, D., Effiong, E., \& Ohen, S. (2009). Analysis of technical and economic efficiencies in rice production systems in the Niger Delta region of Nigeria. Sustaining Agricultural Growth to Meet National Economic Development Goal. Proceedings of the 23rd Annual Conference of the Farm Management Association of Nigeria (FAMAN).

Javed, M. I., Adil, S. A., Javed, M. S., \& Hassan, S. (2008). Efficiency analysis of rice-wheat system in Punjab, Pakistan. Pakistan Journal of Agricultural Sciences, 45, 96-100.

Jilani, A., Pearce, D., \& Bailo, F. (2013). ACIAR wheat and maize projects in Afghanistan. Australian Centre for International Agricultural Research.

Kibaara, B. W. (2005). Technical efficiency in Kenyan's maize production: An application of the stochastic frontier approach. Colorado State University Fort Collins.

Krasachat, W. (2004). Technical efficiencies of rice farms in Thailand: A non-parametric approach. The Journal of American Academy of Business, 4, 64-69.

Maddala, G. S. (1986). Limited-dependent and qualitative variables in econometrics. Cambridge University Press, UK

Maletta, H., \& Favre, R. (2003). Agriculture and food production in post-war Afghanistan. Kabul, FAO and MAAH.

Mangal, M. Q., Hemat, M., Hamayoun, H. L., Ghafari, S. R., \& Jalali, M. N. (2017). Response of maize varieties under variable planting geometry in Kandahar semi-arid situation. International Journal of Applied Research, 3, 74-78.

Martey, E. (2019). The impact of credit on the technical efficiency of maize-producing households in Northern Ghana. Agricultural Finance Review, 79, 304-322. https://doi.org/10.1108/AFR-05-2018-0041

Ministry of Agriculture. (2012). Agricultural Prospects Report. Kabul, Goverment of Afghanistan.

Msuya, E. E., Hisano, S., \& Nariv, T. (2008). Analysis of Technical Efficiency of Maize Farmers in Tanzania: The Globalization Era. XII World Congress of Rural Sociology of the International Rural Sociology Association, Goyang, Korea.

Mussaa, E., Obare, G. A., Bogale, A., \& Simtowe, F. (2011). Resource use efficiency of smallholder crop production in the central highlands of Ethiopia.

Mwalupaso, G. E., Wang, S., Rahman, S., Alavo, E. J.-P., \& Tian, X. (2019). Agricultural Informatization and Technical Efficiency in Maize Production in Zambia. Sustainability, 11, 2451. https://doi.org/10.3390/ su1 1082451

Nchare, A. (2007). Analysis of factors affecting technical efficiency of arabica coffee producers in Cameroon.

Ng'ombe, J., \& Kalinda, T. (2015). A stochastic frontier analysis of technical efficiency of maize production under minimum tillage in Zambia. Sustainable Agriculture Research, 4(2), 31. https://doi.org/10.5539/ sar.v4n $2 \mathrm{p} 31$

Ngabitsinze, J. C. (2014). Analysis of Economic Efficiency of Maize Production in Huye District in Rwanda. International Journal of Agriculture Innovations and Research, 3, 2319-1473.

Nyagaka, D. O., Obare, G. A., Omiti, J. M., \& Nguyo, W. (2010). Technical efficiency in resource use: Evidence from smallholder Irish potato farmers in Nyandarua North District, Kenya. African Journal of Agricultural Research, 5, 1179-1186.

Obaidi, M. Q., Osmanzai, M., \& Rajiv, S. (2012). Zoodras-a new high yielding maize variety for Afghanistan. American-Eurasian Journal of Agricultural \& Environmental Sciences, 12, 1242-1245.

Okike, I., Jabbar, M. A., Manyong, V. M., Smith, J. W., \& Ehui, S. K. (2004). Factors affecting farm-specific production efficiency in the savanna zones of West Africa. Journal of African Economies, 13, 134-165. https://doi.org/10.1093/jae/13.1.134

Olarinde, L. O. (2011). Analysis of technical efficiency differentials among maize farmers in Nigeria.

Peprah, J. A. (2010). Access to credit and technical efficiency of vegetable growers in Mfantsiman District of Ghana. https://doi.org/10.2139/ssrn.1805218

Rajiv Sharma, Q. S., Azmatyar, M. H., \& Mohmand, E. (2018). Three New Maize Hybrids for Afghanistan. Journal of Agricultural Science, 10(6), 349. https://doi.org/10.5539/jas.v10n6p349 
Saleem, S., \& Raouf, M. E. (2011). Sustainable Agricultural Development and the Challenges Facing Agricultural Education in Afghanistan. Journal of Developments in Sustainable Agriculture, 6, 45-49.

Sapkota, M., Joshi, N. P., Kattel, R. R., \& Bajracharya, M. (2017). Technical Efficiency and Its Determinants on Maize Seed Production in Palpa District, Nepal. https://doi.org/10.20944/preprints201705.0067.v1

Sarhadi, W. A., Fahim, S. A., \& Tangutan, K. (2014). Sustainable agricultural development in Afghanistan. Journal of Developments in Sustainable Agriculture, 9, 41-46.

Sekabira, H., \& Qaim, M. (2017). Can mobile phones improve gender equality and nutrition? Panel data evidence from farm households in Uganda. Food Policy, 73, 95-103. https://doi.org/10.1016/j.foodpol. 2017.10.004

Shehu, J., Iyortyer, J., Mshelia, S., \& Jongur, A. (2010). Determinants of yam production and technical efficiency among yam farmers in Benue State, Nigeria. Journal of Social Sciences, 24, 143-148. https://doi.org/10.1080/09718923.2010.11892846

Sibiko, K. W. (2012). Determinants of common bean productivity and efficiency: A case of smallholder farmers in Eastern Uganda.

Sudrajat, I. S., Rahayu, E. S., \& Supriyadi, K. (2018). Effect of Institution on Production Cost Efficiency of Organic Rice Farming in Indonesia. DLSU Business \& Economics Review, 28, 166-175.

Taiwo, O., Dayo, O. S., \& Bolariwa, K. (2014). Technical efficiency analysis of cassava production in Nigeria: Implication for increased productivity and competitiveness. Research Journal of Agriculture and Environmental Management, 3, 569-576.

Tavva, S., Aw-Hassan, A., Rizvi, J., \& Saharawat, Y. S. (2017). Technical efficiency of wheat farmers and options for minimizing yield gaps in Afghanistan. Outlook on Agriculture, 46, 13-19. https://doi.org/ $10.1177 / 0030727016689632$

Thomas, V., \& Ramzi, A. M. (2011). SRI contributions to rice production dealing with water management constraints in northeastern Afghanistan. Paddy and Water Environment, 9, 101-109. https://doi.org/ 10.1007/s10333-010-0228-0

Tijani, A. (2006). Analysis of the technical efficiency of rice farms in Ijesha Land of Osun State, Nigeria. Agrekon, 45(2), 126-135. https://doi.org/10.1080/03031853.2006.9523738

Tobin, J. (1958). Estimation of relationships for limited dependent variables. Econometrica: Journal of the Econometric Society, 26(1), 24-36. https://doi.org/10.2307/1907382

\section{Copyrights}

Copyright for this article is retained by the author(s), with first publication rights granted to the journal.

This is an open-access article distributed under the terms and conditions of the Creative Commons Attribution license (http://creativecommons.org/licenses/by/4.0/). 